УДК 633.11.631.527 DOI 10.31210/visnyk2018.03.09

(C) 2018

Тищенко В. М., доктор сільськогосподарських наук, Гусенкова О. В., здобувач, Дубенець М. В., здобувач, Колісник А. В., кандидат біологічних наук

Полтавська державна аграрна академія

\title{
СИСТЕМАТИЗАЦІЯ СОРТІВ ТА СЕЛЕКЦІЙНИХ ЛІНІЙ ПШЕНИЦІ ОЗИМОЇ ЗА КІЛЬКІСНИМИ ОЗНАКАМИ В УМОВАХ КОНТРОЛЬОВАНОГО СЕРЕДОВИЩА З ВИКОРИСТАННЯМ КЛАСТЕРНОГО АНАЛІЗУ
}

\section{Рецензент - доктор сільськогосподарських наук, професор П. В. Писаренко}

\begin{abstract}
Викладено результати чотирьохрічних досліджень (2013-2016 рр.) із визначення збалансованості кількісних ознак сортів та селекційних ліній пшениці озимої за строками сівби при використанні кластерного аналізу. В досліді використовували 2 строки сівби: ранній (1 вересня, СП-1) і пізній (1 жовтня, СП3). Головною метою при аналізі кращих груп $i$ кластерів був пошук сортів і селекційних ліній (СЛ) пшенииі озимої, які в статистичному аналізі мали високі показники двох складових врожаю - кількість зерен в колосі (К3) та маса зерна з колосу (М1). Також було досліджено як в краших групах $i$ на дендрограмах виділялись сорти і генотипи, які були кращими як в першому, так $і$ в третьому строкові сівби не лише за K3 $i$ M1, а й за іншими господарськи цінним ознакам $i$ за врожайністю.

У результаті кластерного аналізу були сформовані групи сортів та селекційних ліній пшениці озимої, в яких міститься інформація про рівень формування ознак за ранніх та пізніх строків сівби. Нами були виділені генотипи пшениці озимої, як носії високого рівня кількісних ознак, особливо ознак потенціалу врожайності за ранніх та пізніх строків сівби, які можна використовувати як перспективний селекційний матеріал.
\end{abstract}

Перевага кластерного аналізу по відношенню до статистичного аналізу полягає в тому, щзо кластерний аналіз дає змогу ідентифікувати сорти і селекизіині лінії по збалансованості за господарськи корисними ознаками, а в статистичному аналізі ми можемо відібрати і виділити тільки окремі кількісні ознаки по їх рівню формування $i$ мінливості $i$ за врожайністю.

Ключові слова: пшениця озима, ознаки, строки сівби, кластерний аналіз.

Постановка проблеми. Протягом 2013-2016 років у спеціальному досліді за строками сівби ми вивчали рівень формування і мінливість двох дуже важливих ознак потенціалу врожайності - кількості зерен з колосу (КЗ) та маси зерна з колосу (М1). Щорічно за матеріалами досліджень відбирались кращі генотипи за максимальним рівнем формування ознак M1 і КЗ. Велика увага в аналізах приділялась стабільності утримання рівня формування ознак сортів і селекційних ліній (СЛ) за строками сівби. Відомо, що стабільність утримання рівня формування ознак за строками сівби визначають рівень адаптивного потенціалу. В попередніх наших публікаціях повідомлялось про рівень стабільності кількісних ознак у сортів пшениці озимої і про те, що збалансованість ознак більш повніше визначає адаптивний потенціал того чи іншого сорту пшениці озимої $[1,2,9]$.

У дослідженнях минулих років ми визначили, що ефективним методом і підходом в пошуках генотипів збалансованих за господарськи корисними ознаками, $є$ кластерний аналіз з використанням групуючих ознак - (M5) маса стебла й індексу лінійної щільності колосу (КЗ/ДК (кількість зерен в колосі/довжина колоса)). Тому в подальших дослідженнях із вивчення рівня формування і мінливості кількісних ознак пшениці озимої, за роками досліджень (2013-2016) і строками сівби, нами був проведений кластерний аналіз. За результатами кластерного аналізу визначився кращий кластер (КК) та краща група (КГ) кращого кластеру, в якій сформувалися генотипи збалансовані за господарськи корисними ознаками.

Аналіз основних досліджень і публікацій, у яких започатковано розв'язання проблеми. Генетична різноманітність пшениці служить джерелом варіацій для селекції, обумовлюючи створення нових форм господарськи цінних рослин 3 поліпшеними властивостями. Вузька генетична основа знижує ефективність селекції, оскільки не дозволяе подолати вразливість до несприятливих факторів і обмежує можливості комбінаторики спадкового матеріалу при гібридизації. У зв'язку з цим важливого значення набуває збереження генетичних ресурсів і оцінка їх різноманітності для подальшого використання в практичних цілях [12].

У своїй роботі селекціонер часто стикається 3 великим обсягом матеріалу з цілого набору різних за своєю природою ознак, який необхідно якимось чином систематизувати, щоб виділити кращі форми за комплексом господарськи цін- 


\section{СІЛЬСЬКЕ ГОСПОДАРСТВО. РОСЛИННИЦТВО}

них ознак [5]. Однією з проблем для дослідника при вивченні різноманітності генетичних колекцій рослин $є$ аналіз великого масиву даних. Як правило, основним статистичним методом класифікації даних, який широко використовується, $\epsilon$ кластерний аналіз, що дозволяє структурувати колекційні зразки [4]. Відомо, що кластерний аналіз у дослідженнях застосовується на м'якій пшениці при вивченні ступеня генетичної спорідненості $[13,3,6]$. Специфічним для досліджень в області селекції $є$ те, що ознаки аналізу структури врожайності оцінюються і вимірюються в шкалах різного типу і з різною кількістю градацій. Тому, в залежності від шкали ознаки, необхідно вибирати і відповідний коефіцієнт подібності. Розглядається можливість застосування алгоритмів кластерного аналізу для вирішення завдань, пов'язаних із групуванням за ознаками колоса, які аналізуються. Це, зрештою, надасть селекціонерові відчутну допомогу при проведенні доборів [7].

Ідентифікація сортів та селекційних ліній пшениці озимої в кластерному аналізі дає змогу виділити генотипи 3 мінімальною Евклідовою відстанню між кількісними ознаками, що підтверджує високий рівень збалансованості основних генеративних, вегетативних ознак та урожайності цих генотипів. Використання кластерного аналізу для ідентифікації генотипів наближає нас до створення теоретичної і практичної моделі сорту пшениці озимої, в якого сприятливе співвідношення кількісних та якісних ознак дає можливість протистояти негативним впливам навколишнього середовища та формувати високу продуктивність [8, 10, 11].

Мета досліджень. Головною метою був пошук сортів і СЛ пшениці озимої в кластерному аналізі, які в статистичному аналізі мали високі показники двох складових врожаю - К3 та M1, а також ідентифікувати сорти і константні селекційні лінії, які були кращими за двома строками сівби та збалансовані за господарськи цінними ознаками та за врожайністю.

Завданням досліджень було проведення статистичного та кластерного аналізів кількісних ознак пшениці озимої.

Матеріали і методи досліджень. Матеріалом дослідження були сорти та селекційні лінії озимої пшениці, які вирощувались на селекційних ділянках впродовж 2013-2016 років. За досліджуваними сортами та селекційними лініями (СЛ) проводився структурний аналіз по 25 рослинах, які вирізали на дослідних ділянках, доводили до повітряно-сухого стану та проводили 3 кожною рослиною вимірювання, підрахунки, зважування. В аналіз залучали велике різноманіття кількісних ознак: урожайність, ц; маса зерна 3 колоса (M1), г; маса колоса із насінням (М3), г; кількість зерен в колосі (К3), шт; маса тисячі зерен (МТ3), г; висота рослини (Н), см; довжина верхнього міжвузля (ДВМ), см; довжина колоса (ДК), см; маса рослини (М2), г; маса стебла (M5), г; маса полови (M4), г; та селекційних індексів таких як: НI - збиральний індекс (M1/M2); AI - індекс атракції (M3/M5); Мic - індекс мікророзпозділів (M1/M4); ІЛЩК - індекс лінійної щільності колосу (КЗ/ДК); РI - полтавський індекс (М1/ДВМ). Статистичні обрахунки та кластерний аналіз проводили за допомогою програми «STATISTICA 10».

Результати досліджень. В 2013 році із 106 сортів та СЛ, включених в кластерний аналіз за першим строком сівби (табл. 1), в кращій групі 6-го кластеру сконцентрувалося 5 генотипів (2 сорти: №396 (Славна), №398 (Спасівка); і 3 селекційні лініï: №378 (Перемога $2 \times$ Коломак 3 ) × ×танічна; №381 (Перемога $2 \times$ Коломак 5) ×Станічна; №387 (Перемога $2 \times$ Коломак 5)×Станічна). Слід відмітити, що в кращих кластерах ідентифікуються сорти та СЛ, які мають найвищі показники кількісних ознак i селекційних індексів, у тому числі й врожайності.

У СП-3 (табл. 1) в кращій 2-й групі 6-го кластеру виділились 16 сортів і СЛ, які мали досить високі показники як генеративних, так і вегетативних ознак. Слід відмітити, що врожайність по кращій групі кращого кластеру в СП-1 була вищою, ніж у кращій групі кращого кластеру СП-3. Пояснюється це тим, що досить складні погодні умови склалися для пізнього строку сівби. Якщо по СП-1 були отримані сходи своєчасно за наявності вологи на 1 вересня, то на період 1 жовтня (СП-3) вологи було обмаль і, крім того, час відновлення весняної вегетації пшениці озимої був пізній (ЧВВВ - 5 квітня), а весняний період вегетації пшениці озимої (квітень - травень) був сухим. Незважаючи на складні умови органогенезу пшениці озимої для пізнього строку сівби в досліді формувались генотипи, які мали достатньо високий рівень врожайності 2,25 т/га і високий рівень формування генеративних ознак (M1 - 2,1 г); M3 - 3,1; K3 - 54,4; MT3 - 44,5 г).

Слід відмітити, що деякі сорти та СЛ, які були кращими по M1 і К3 в статистичному аналізі, були ідентифіковані в кращі кластери і групи в кластерному аналізі - по М1 - №396 с. Славна; №417 с. Говтва; №398 с. Спасівка; по К3 - №396 с. Славна; №378 СЛ (Перемога $2 \times$ Коломак 3)×Зерноград 11. За наслідками важких кліматичних умов 2013 року на дендрограмах СП-1 та СП-3 (рис. 1,2 ) сорти та селекційні лінії пшениці озмої не співпадають, що пояснюється недостатнім адаптивним потенціалом генотипів. 
СІЛЬСЬКЕ ГОСПОДАРСТВО. РОСЛИННИЦТВО

\section{1. Рівень формування кількісних ознак та селекційних індексів сортів та селекційних ліній пшениці озимої кращих груп, кращих кластерів, 2013 рік}

\begin{tabular}{|c|c|c|c|c|}
\hline \multirow{2}{*}{$\begin{array}{c}\text { Ознаки та } \\
\text { індекси }\end{array}$} & \multicolumn{2}{|c|}{ СП-1, К6, Г2 } & \multicolumn{2}{c|}{ СП-3, К6, Г2 } \\
\cline { 2 - 5 } & $\bar{x}$ & $\mathrm{LV}$ & $\bar{x}$ & $\mathrm{LV}$ \\
\hline Урожайність & $23,7 \pm 4,6$ & $18,8-28,1$ & $12,1 \pm 4,7$ & $5,3-22,5$ \\
\hline М1 & $2,8 \pm 0,4$ & $2,2-3,1$ & $1,9 \pm 0,1$ & $1,6-2,1$ \\
\hline М3 & $3,9 \pm 0,4$ & $3,4-4,4$ & $2,7 \pm 0,2$ & $2,5-3,1$ \\
\hline К3 & $61,5 \pm 7,6$ & $51,9-69,9$ & $45,7 \pm 3,9$ & $39,9-54,4$ \\
\hline МТ3 & $44,9 \pm 2,3$ & $42,6-48,0$ & $40,9 \pm 2,2$ & $37,4-44,5$ \\
\hline H & $72,3 \pm 11,1$ & $58,3-82,2$ & $55,6 \pm 5,9$ & $47,1-67,1$ \\
\hline ДВМ & $20,9 \pm 6,0$ & $14,2-26,7$ & $21,6 \pm 1,6$ & $18,6-24,6$ \\
\hline ДК & $10,0 \pm 0,4$ & $9,4-10,5$ & $7,7 \pm 0,5$ & $6,8-8,5$ \\
\hline М2 & $5,6 \pm 0,7$ & $4,6-6,3$ & $3,5 \pm 0,3$ & $3,1-4,0$ \\
\hline М5 & $1,7 \pm 0,3$ & $1,2-2,0$ & $0,8 \pm 0,1$ & $0,6-1,0$ \\
\hline М4 & $1,1 \pm 0,1$ & $1,1-1,3$ & $0,8 \pm 0,1$ & $0,6-1,0$ \\
\hline HI & $49,4 \pm 0,8$ & $48,1-5,4$ & $53,3 \pm 2,5$ & $49,6-58,4$ \\
\hline АІ & $2,4 \pm 0,3$ & $2,0-2,8$ & $3,3 \pm 0,4$ & $2,6-4,2$ \\
\hline Міс & $2,4 \pm 0,3$ & $1,9-2,9$ & $2,3 \pm 0,4$ & $1,8-3,1$ \\
\hline ІЛЩК & $6,2 \pm 1,0$ & $4,9-7,4$ & $6,0 \pm 0,6$ & $4,8-7,0$ \\
\hline РI & $13,9 \pm 3,1$ & $10,6-18,7$ & $8,7 \pm 0,9$ & $7,4-10,3$ \\
\hline
\end{tabular}

*Примітка: М1 - маса зерна з колоса, г; М3 - маса колоса із насінням, г; К3 - кількість зерен в колосі, шт.; МТЗ - маса тисячі зерен, г; Н - висота рослини, см; ДВМ - довжина верхнього міжвузля, см; ДК - довжина колоса, см; М2 - маса рослини, г; М5 - маса стебла, г; М4 - маса полови, г; НІ збиральний індекс (M1/M2); АI - індекс атракції (M3/M5); Міс - індекс мікророзпозділів (M1/M4); ІЛЩК - індекс лінійної щільності колосу (КЗ/ДК); РІ - полтавський індекс (М1/ДВМ); $\bar{x}$ - середнє арифметичне; LV - ліміти варіювання; К - кластер, Г - група.

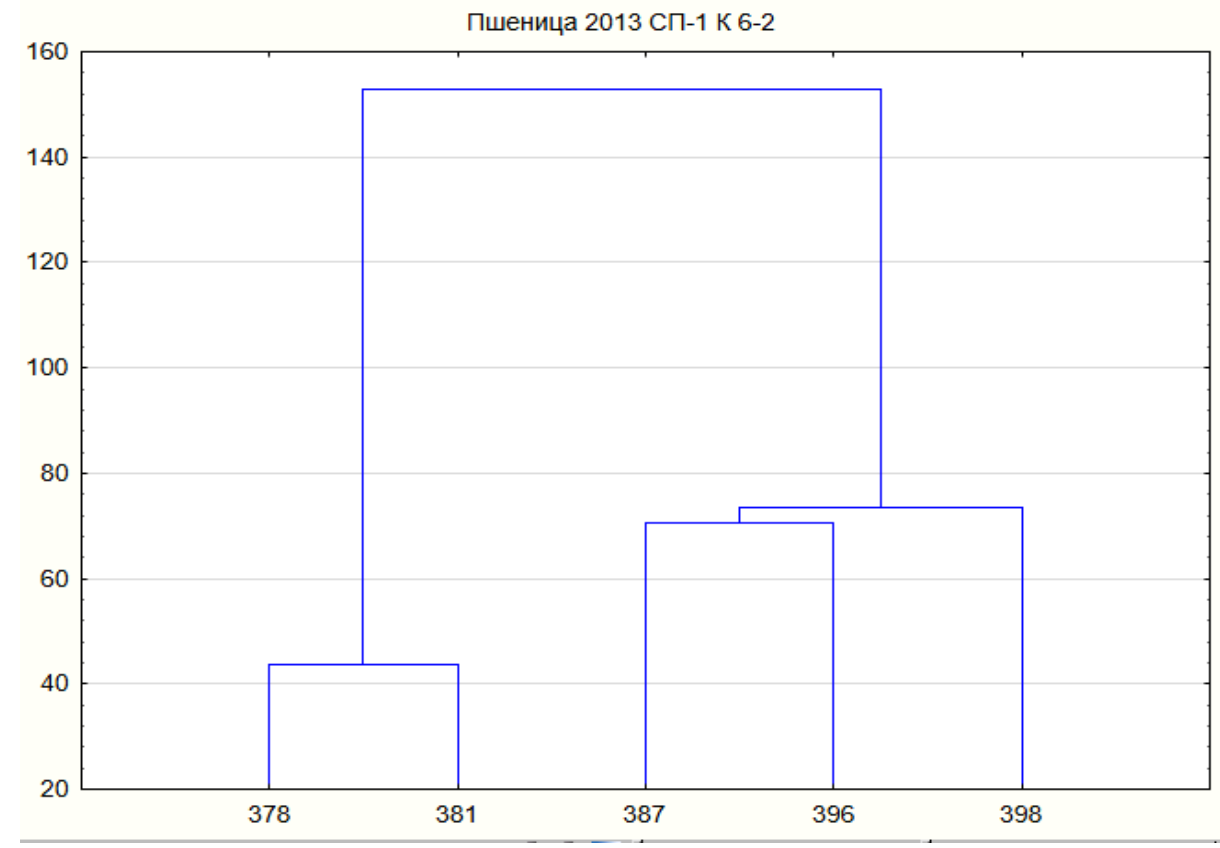

Рис. 1. Дендрограма розподілу сортів та селекційних ліній пшениці озимої в КГ 6-го кластеру, 2013 р., СП-1 


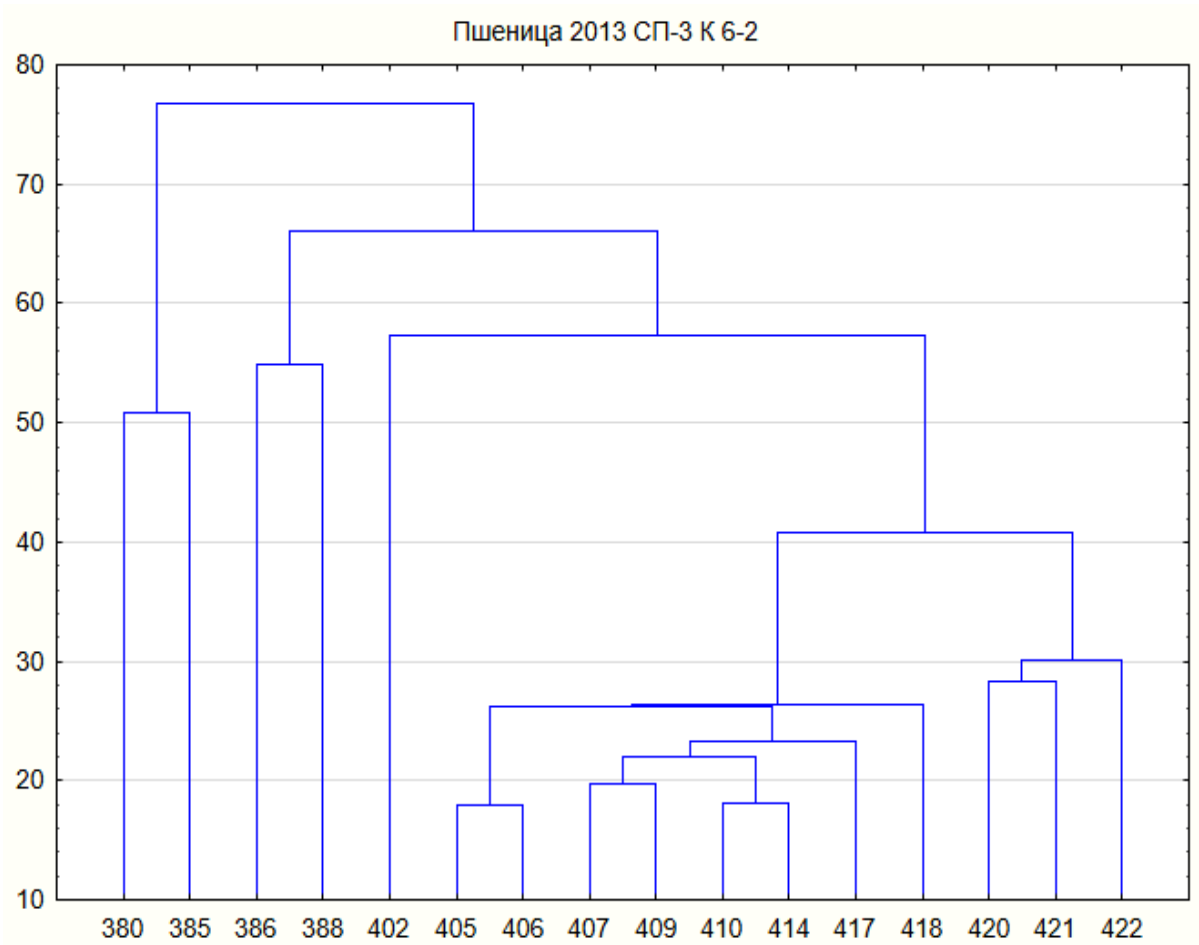

Рис. 2. Дендрограма розподілу сортів та селекційних ліній пщениці озимої в КГ 6-го кластеру, 2013 р., СП-3

2. Рівень формування кількісних ознак та селекційних індексів сортів та селекційних ліній пшениці озимої кращих груп, кращих кластерів, 2014 рік

\begin{tabular}{|c|c|c|c|c|}
\hline \multirow{2}{*}{ Ознаки та індекси } & \multicolumn{2}{|c|}{ СП-1, К6, Г5 } & \multicolumn{2}{c|}{ CП-3, К6, Г5 } \\
\cline { 2 - 5 } & $\bar{x}$ & $\mathrm{LV}$ & $\bar{x}$ & $\mathrm{LV}$ \\
\hline Урожайність & $8,9 \pm 6,2$ & $3,1-21,6$ & $43,6 \pm 9,0$ & $33,1-63,0$ \\
\hline М1 & $2,5 \pm 0,2$ & $2,1-2,7$ & $2,3 \pm 0,2$ & $2,0-2,6$ \\
\hline М3 & $3,5 \pm 0,3$ & $2,8-3,8$ & $3,1 \pm 0,2$ & $2,7-3,6$ \\
\hline К3 & $64,7 \pm 2,8$ & $59,2-67,8$ & $56,6 \pm 2,1$ & $53,7-61,6$ \\
\hline МТ3 & $39,3 \pm 4,3$ & $32,8-46,1$ & $40,0 \pm 2,9$ & $34,5-44,0$ \\
\hline Н & $69,0 \pm 7,0$ & $62,1-78,0$ & $80,9 \pm 3,7$ & $75,6-87,8$ \\
\hline ДВ & $21,7 \pm 2,7$ & $18,4-25,9$ & $28,2 \pm 3,1$ & $20,3-32,1$ \\
\hline ДК & $9,7 \pm 0,6$ & $8,8-10,2$ & $9,1 \pm 0,2$ & $8,7-9,4$ \\
\hline М2 & $5,4 \pm 0,4$ & $4,6-5,6$ & $4,8 \pm 0,3$ & $4,3-5,4$ \\
\hline М5 & $1,8 \pm 0,1$ & $1,7-2,0$ & $1,7 \pm 0,1$ & $1,6-2,0$ \\
\hline М4 & $1,0 \pm 0,2$ & $0,7-1,1$ & $0,9 \pm 0,1$ & $0,7-1,0$ \\
\hline НІ & $47,4 \pm 2,3$ & $43,9-51,5$ & $46,7 \pm 1,7$ & $43,9-49,2$ \\
\hline АІ & $2,0 \pm 0,2$ & $1,6-2,1$ & $1,8 \pm 0,1$ & $1,5-2,0$ \\
\hline Мі & $2,6 \pm 0,4$ & $2,1-3,1$ & $2,6 \pm 0,3$ & $2,2-3,2$ \\
\hline ІЛЩК & $6,7 \pm 0,2$ & $6,4-7,1$ & $6,2 \pm 0,2$ & $6,0-6,5$ \\
\hline РІ & $11,9 \pm 2,2$ & $8,1-14,7$ & $8,1 \pm 0,9$ & $6,9-10,0$ \\
\hline
\end{tabular}

*Примітка: М1 - маса зерна 3 колоса, г; М3 - маса колоса із насінням, г; К3 - кількість зерен в колосі, шт.; МТЗ - маса тисячі зерен, г; Н - висота рослини, см; ДВМ - довжина верхнього міжвузля, см; ДК - довжина колоса, см; М2 - маса рослини, г; М5 - маса стебла, г; М4 - маса полови, г; НІ збиральний індекс (M1/M2); AI - індекс атракції (M3/M5); Мic - індекс мікророзпозділів (M1/M4); ІЛЩК - індекс лінійної щільності колосу (КЗ/ДК); РІ - полтавський індекс (М1/ДВМ); $\bar{x}-$ середнє арифметичне; LV - ліміти варіювання; К - кластер, Г - група. 
За результатами кластерного аналізу раннього строку сівби (СП-1) 2014 року, встановлено, що 5-та група 6-го кластеру була кращою, в яку ввійшли із 106 сортів та СЛ - 6 генотипів, з яких один сорт №449 - Іванівська остиста і 5 константних СЛ - №414-(Коломак 2×Червона), №424(Сонячна $\times$ Коломак 5), №425-(Сонячна $\times$ Коломак 5), №427-(Українка полтавська $\times$ Станічна), №480-(Перемога $2 \times$ Коломак 3) ×Зерноград 11, №487- (Перемога $2 \times$ Коломак 5) $\times$ Станічна. Сорти та селекційні лінії цієї групи мали високий рівень формування кількісних ознак (табл. 2).

За пізнього строку сівби (СП-3) кращою була 5-та група 6-го кластеру, в яку ввійшли 14 сортів та селекційних ліній. Причому 3 константні селекційні лінії №425, №487, №427 були кращими як в СП-3, так і в СП-1, тобто, ці 3 СЛ були кращими за всіма кількісними ознаками і врожайністю (табл. 2). Нами раніше було досліджено [8, $10,11]$, що генотипи, які попадають в кращі групи кластерів першого і третього строків сівби, збалансовані за багатьма кількісними ознаками, особливо за ознаками потенціалу врожайності. Ці генотипи представляють особливу зацікавленість як перспективний селекційний матеріал. Якщо вважати строки сівби додатковим контрольованим середовищем в органогенезі пшениці озимої, а це нами доведено по цілому ряду досліджень на великій вибірці і протягом багатьох років $[8,10,11]$, коли він не змінює рівень формування ознак за строками сівби, відіграє велику роль в стабільності потенціалу врожайності і адаптивності сорту пшениці озимої.

За результатами аналізу дендрограм за строками сівби (СП-1, СП-3) видно (рис. 3, 4), що кращі генотипи, які потрапили в кращі кластери і кращі групи, мають майже однакову висоту стовпчика на дендрограмі і однакову сумарну відстань за Евклідовою метрикою. Такий збіг свідчить про високий адаптивний потенціал досліджуваного матеріалу пшениці озимої.

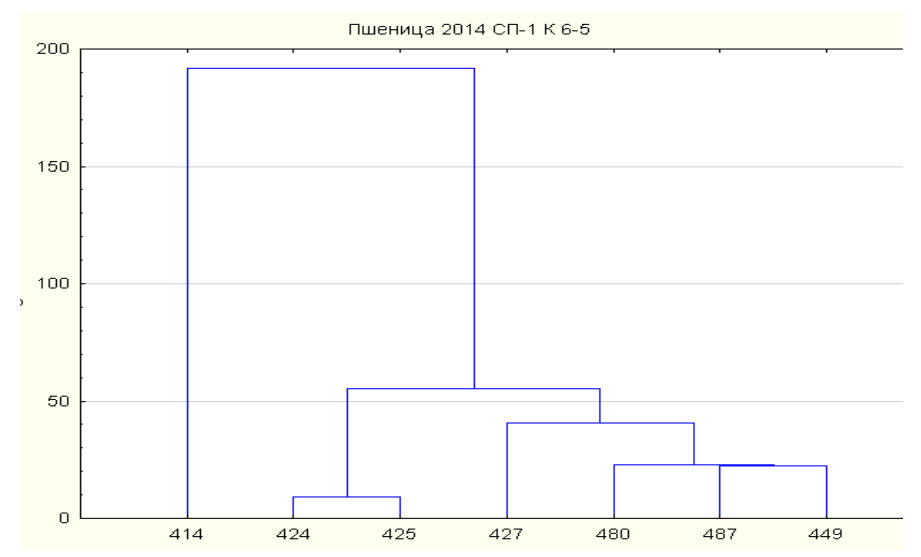

Рис. 3. Дендрограма розподілу сортів та селекційних ліній пиениці озимої в КГ 6-го кластеру, 2014 р., СП-1

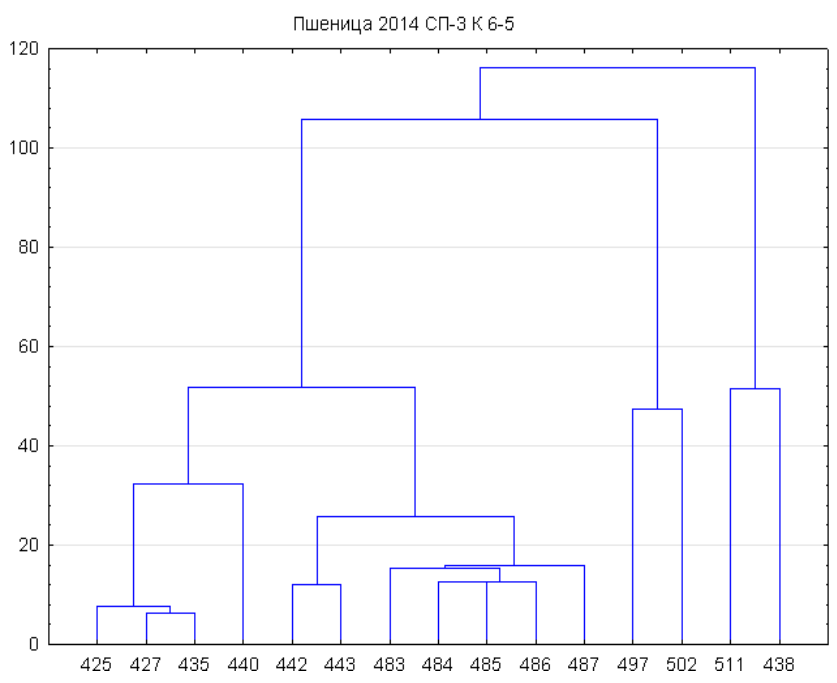

Рис. 4. Дендрограма розподілу сортів та селекційних ліній пшениці озимої в КГ 6-го кластеру, 2014 р., СП-3 
СІЛЬСЬКЕ ГОСПОДАРСТВО. РОСЛИННИЦТВО

\section{3. Рівень формування кількісних ознак та селекційних індексів сортів та селекційних ліній пшениці озимої кращих груп, кращих кластерів, 2015 рік}

\begin{tabular}{|c|c|c|c|c|}
\hline \multirow[t]{2}{*}{ Ознаки та індекси } & \multicolumn{2}{|c|}{ СП-1, К6, Г5 } & \multicolumn{2}{|c|}{ СП-3, К6, Г6 } \\
\hline & $\bar{x}$ & LV & $\bar{x}$ & LV \\
\hline Урожайність & $14,5 \pm 4,8$ & $6,9-23,8$ & $31,0 \pm 6,4$ & $24,7-43,1$ \\
\hline $\mathrm{M}_{1}$ & $3,9 \pm 0,2$ & $3,5-4,4$ & $3,6 \pm 0,3$ & $3,1-4,0$ \\
\hline $\mathrm{M} 3$ & $5,2 \pm 0,3$ & $4,8-5,9$ & $4,9 \pm 0,5$ & $4,0-5,3$ \\
\hline К3 & $80,1 \pm 4,0$ & $72,8-89,6$ & $77,4 \pm 3,7$ & $72,2-81,5$ \\
\hline MT3 & $48,2 \pm 1,8$ & $45,0-52,7$ & $47,1 \pm 3,5$ & $41,2-51,8$ \\
\hline $\mathrm{H}$ & $80,9 \pm 3,0$ & $74,0-86,6$ & $83,3 \pm 7,1$ & $76,1-96,1$ \\
\hline ДВМ & $32,9 \pm 1,5$ & $30,3-35,3$ & $33,8 \pm 3,3$ & $30,1-39,5$ \\
\hline ДК & $10,8 \pm 0,6$ & $10,3-12,9$ & $10,7 \pm 0,5$ & $10,0-11,4$ \\
\hline $\mathrm{M} 2$ & $7,6 \pm 0,4$ & $7,1-8,8$ & $7,2 \pm 0,5$ & $6,2-7,7$ \\
\hline M5 & $2,4 \pm 0,2$ & $2,3-2,9$ & $2,3 \pm 0,1$ & $2,1-2,4$ \\
\hline $\mathrm{M} 4$ & $1,3 \pm 0,1$ & $1,1-1,6$ & $1,2 \pm 0,2$ & $0,9-1,4$ \\
\hline $\mathrm{HI}$ & $50,9 \pm 1,4$ & $48,6-53,4$ & $50,9 \pm 1,0$ & $50,1-52,7$ \\
\hline AI & $2,2 \pm 0,1$ & $2,0-2,4$ & $2,1 \pm 0,1$ & $1,9-2,2$ \\
\hline Mic & $2,9 \pm 0,2$ & $2,6-3,5$ & $3,0 \pm 0,3$ & $2,7-3,6$ \\
\hline ІЛЩК & $7,4 \pm 0,4$ & $6,4-8,1$ & $7,2 \pm 0,2$ & $6,9-7,5$ \\
\hline PI & $11,7 \pm 0,8$ & $10,3-13,2$ & $10,9 \pm 1,7$ & $7,8-12,7$ \\
\hline
\end{tabular}

*Примітка: М1 - маса зерна 3 колоса, г; М3 - маса колоса із насінням, г; К3 - кількість зерен в колосі, шт.; МТЗ - маса тисячі зерен, г; Н - висота рослини, см; ДВМ - довжина верхнього міжвузля, см; ДК - довжина колоса, см; М2 - маса рослини, г; М5 - маса стебла, г; М4 - маса полови, г; НІ - збиральний індекс (M1/M2); AI індекс атракції (М3/M5); Міс - індекс мікророзпозділів (M1/M4); ІЛЩК - індекс лінійної щільності колосу (КЗ/ДК); РІ - полтавський індекс (М1/ДВМ); $\bar{x}$ - середнє арифметичне; LV - ліміти варіювання; К - кластер, Г - група.

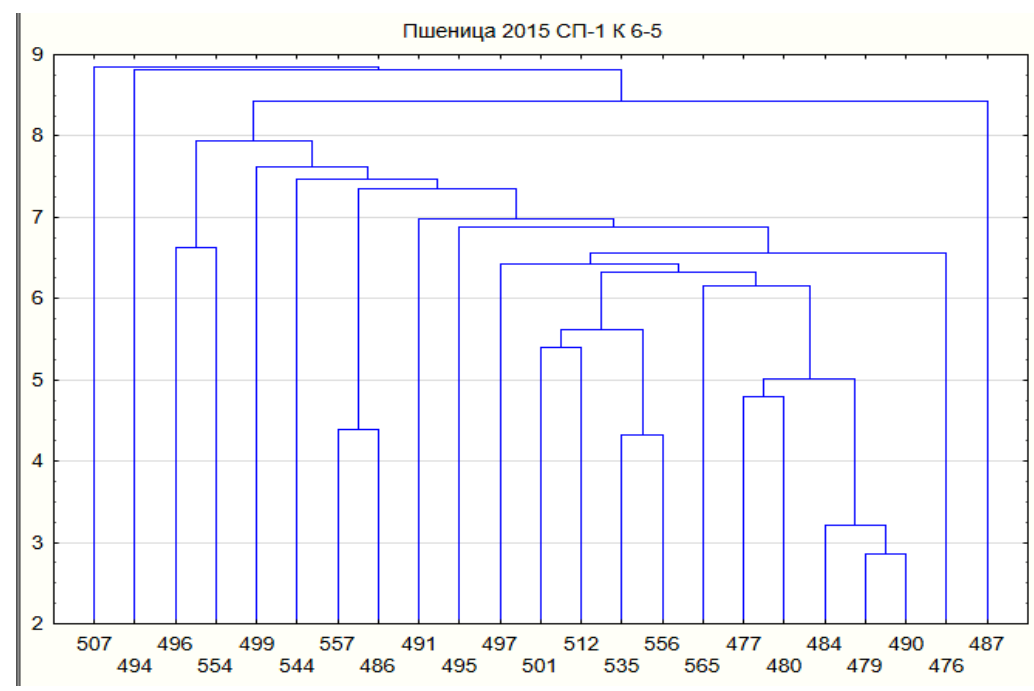

\section{Рис. 5. Дендрограма розподілу сортів та селекційних ліній пщениці озимої} в КГ 6-го кластеру, 2015 р., СП-1

У 2015 році в СП-1 в кращому кластері та кращій групі кластера сконцентрувалися 23 сорти та селекційні лінії пшениці озимої урожайність яких була в межах від 6,9 до 23,8 ц/га, а в СП-3 - 7 сортів та селекційних ліній (табл. 3) урожайність - від 24,7 до 43,1. Слід відмітити, що 3 генотипи (с. Тамань, СЛ №496-(Лінія $9 \times$ Червона) $\times$ Станічна, №499-Лорд $\times$ GASTEL) були кращими за формуванням господарськи корисних ознак як в СП-1, так і в СП-3.

На дендрограмах (рис. 5, 6) представлені сорти та СЛ, які ввійшли в кращі групи за двома строками сівби. Як видно з рис. 5, 6, висота стовпчика і сумарна відстань майже однакові по двом строкам сівби, крім сорту Тамань, де сумарна відстань була вищою в Евклідовому вимірюванні по відношенню до СП-1. 


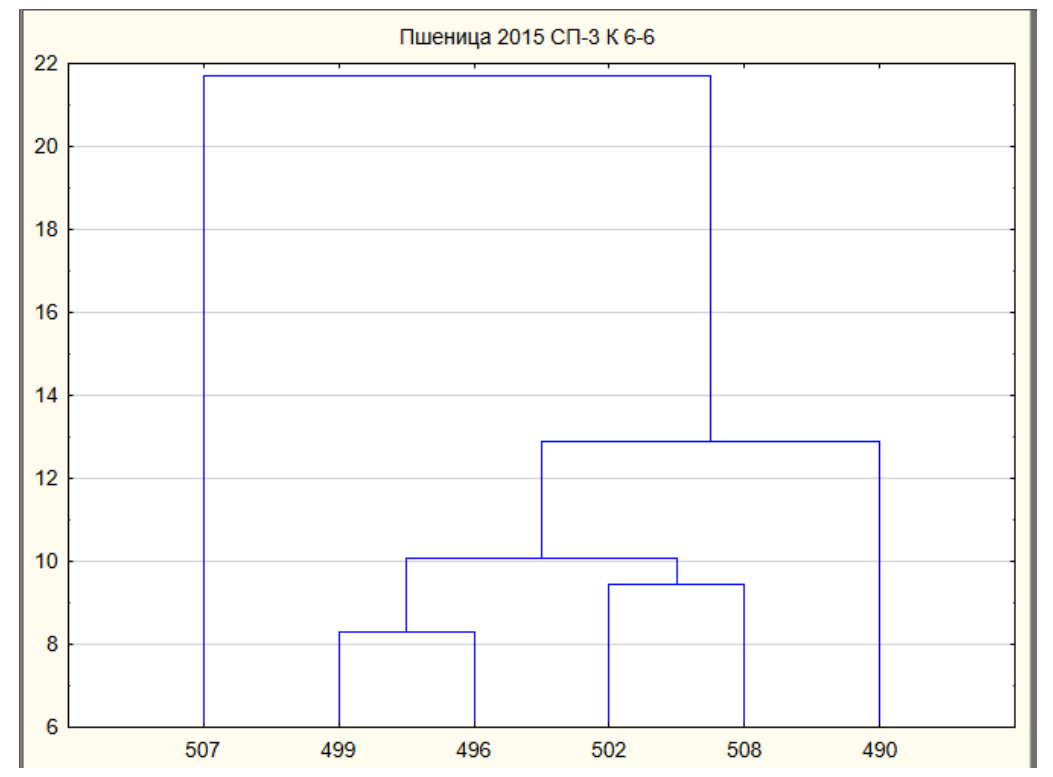

Рис. 6. Дендрограма розподілу сортів та селекційних ліній пиениці озимої в КГ 6-го кластеру, 2015 р., СП-3

\section{4. Рівень формування кількісних ознак та селекційних індексів сортів та селекційних ліній} пшениці озимої кращих груп, кращих кластерів, 2016 рік

\begin{tabular}{|c|c|c|c|c|}
\hline \multirow{2}{*}{ Ознаки та індекси } & \multicolumn{2}{|c|}{ СП-1, К6, Г6 } & \multicolumn{2}{c|}{ CП-3, К6, Г5 } \\
\cline { 2 - 5 } & $\bar{x}$ & LV & $\bar{x}$ & LV \\
\hline Урожайність & $6,4 \pm 9,0$ & $6,4-29,1$ & $5,6 \pm 7,7$ & $5,6-22,8$ \\
\hline М1 & $2,7 \pm 0,2$ & $2,3-3,1$ & $2,6 \pm 0,2$ & $2,1-2,8$ \\
\hline М3 & $3,6 \pm 0,3$ & $3,1-4,1$ & $3,4 \pm 0,3$ & $2,8-3,7$ \\
\hline К3 & $62,2 \pm 3,5$ & $56,8-66,8$ & $61,3 \pm 4,3$ & $56,1-75,6$ \\
\hline МТ3 & $42,9 \pm 3,1$ & $35,9-46,7$ & $41,9 \pm 3,8$ & $34,4-46,5$ \\
\hline H & $79,1 \pm 5,0$ & $71,0-87,0$ & $77,5 \pm 4,8$ & $67,4-84,1$ \\
\hline ДВ & $30,6 \pm 3,3$ & $22,1-34,8$ & $31,9 \pm 3,5$ & $24,6-35,8$ \\
\hline ДК & $9,8 \pm 0,5$ & $9,0-10,6$ & $9,5 \pm 0,6$ & $8,5-11,2$ \\
\hline М2 & $5,4 \pm 0,4$ & $4,9-6,1$ & $5,2 \pm 0,4$ & $4,3-5,6$ \\
\hline М5 & $1,8 \pm 0,1$ & $1,7-2,0$ & $1,7 \pm 0,1$ & $1,5-1,9$ \\
\hline М4 & $0,9 \pm 0,1$ & $0,7-1,0$ & $0,9 \pm 0,1$ & $0,7-1,0$ \\
\hline HI & $49,3 \pm 1,3$ & $46,9-50,9$ & $49,7 \pm 1,6$ & $47,0-52,3$ \\
\hline АІ & $1,9 \pm 0,1$ & $1,6-2,2$ & $2,0 \pm 0,2$ & $1,8-2,3$ \\
\hline Міс & $3,0 \pm 0,2$ & $2,6-3,4$ & $2,9 \pm 0,1$ & $2,6-3,1$ \\
\hline ІЛЩК & $6,3 \pm 0,2$ & $5,8-6,7$ & $6,5 \pm 0,3$ & $6,0-7,4$ \\
\hline РІ & $8,8 \pm 1,1$ & $7,3-10,4$ & $8,1 \pm 1,1$ & $5,9-10,4$ \\
\hline
\end{tabular}

*Примітка: М1 - маса зерна з колоса, г; М3 - маса колоса із насінням, г; К3 - кількість зерен в колосі, шт; МТ3 маса тисячі зерен, г; Н - висота рослини, см; ДВМ - довжина верхнього міжвузля, см; ДК - довжина колоса, см; М2 - маса рослини, г; М5 - маса стебла, г; М4 - маса полови, г; НI - збиральний індекс (М1/M2); AI - індекс атракції (М3/M5); Міс - індекс мікророзпозділів (М1/M4); ІЛЩК - індекс лінійної щільності колосу (К3/ДК); РІ - полтавський індекс (M1/ДВМ); $\bar{x}$ - середнє арифметичне; LV - ліміти варіювання; К - кластер, Г - група.

Слід зазначити, що вивчення сортів, або СЛ за строками сівби дає унікальні можливості оцінити досліджуваний матеріал за рівнем формування кількісних ознак. Ми можемо сформувати групи сортів чи СЛ, де будемо мати інформацію про рівень формування ознак при ранніх, оптимальних або пізніх строках сівби. Також можемо виділити генотипи як носії високого рівня кількісних ознак, особливо ознак потенціалу врожайності за ранніх чи при пізніх строків сівби, 
так як звичайний статистичний аналіз не дає інформації про збалансованість ознак, в тому чи іншому сорті пшениці озимої. Ми вважаємо, що тільки кластерний аналіз дає змогу ідентифікувати сорти 3 використанням Евклідової метрики по рівню збалансованості кількісних ознак.

В 2016 році при аналізі СП-1 в кращу 6-ту групу шостого кластеру згрупувалося 16 сортів та СЛ, 3 яких 6 сортів пшениці озимої (3 полтавської селекції і 3 іншого походження) та 6 константних селекційних ліній. Всі генотипи цього кластеру мали дуже високі показники майже всіх генеративних ознак (табл. 4). Особливо високе значення мала ознака «кількість зерен в колосі» (К3) - 62,2 $\pm 3,5$ штук з максимальним значенням по групі кластеру 66,8 штук. Слід відмітити, що в статистичному аналізі за строками сівби $[1,2$, 9] випробувані генотипи за кращою групою кла- стерного аналізу ввійшли в групу, де кількість зерен в колосі перевищувала 50 штук, а маса зерна 3 колоса (M1) формувалася більше 2 грамів. Вочевидь головним критерієм групування генотипів в кращих кластерах і кращих групах були головні ознаки потенціалу врожайності - «кількість зерен в колосі» і «маса зерна 3 колосу».

Результати кластерного аналізу за СП-3 показали, що кращим був 6-й кластер, а кращою групою - 5-та група цього кластеру, в якій сконцентрувалося 16 сортів та СЛ. Причому, так як і в СП-1, в кращу групу ввійшли 6 сортів і та 6 константних селекційних ліній.

За першого строку сівби, за аналізом дендрограми (рис. 7), сумарна відстань за Евклідовою метрикою була від 2 до 14 одиниць, а в третьому строкові сівби (рис. 8) - від 0 до 25 одиниць.

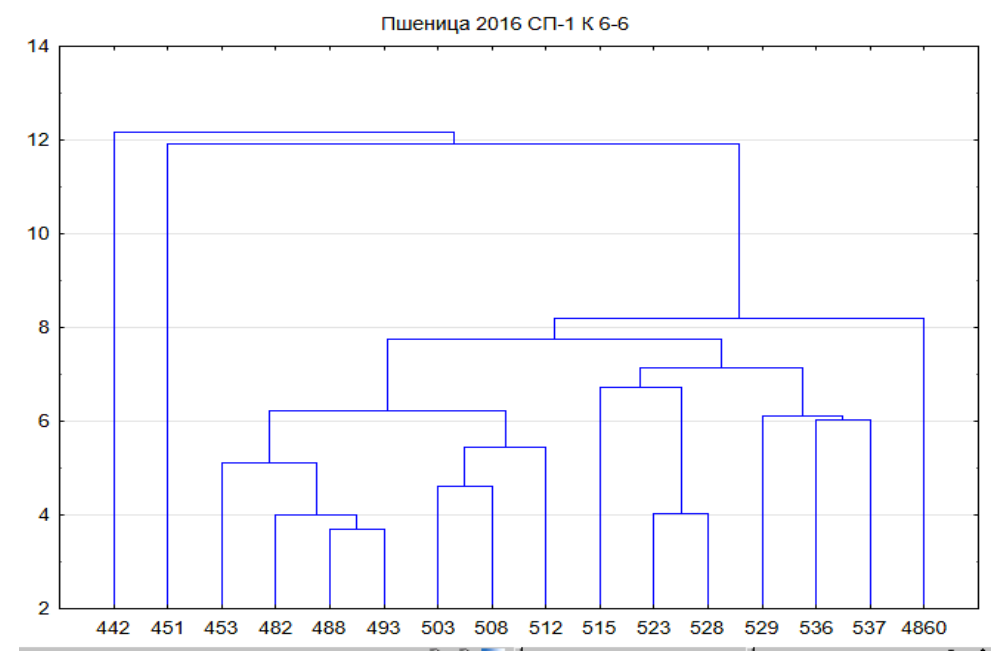

Рис. 7. Дендрограма розподілу сортів та селекційних ліній пиениці озимої в КГ 6-го кластеру, 2016 р., СП-1

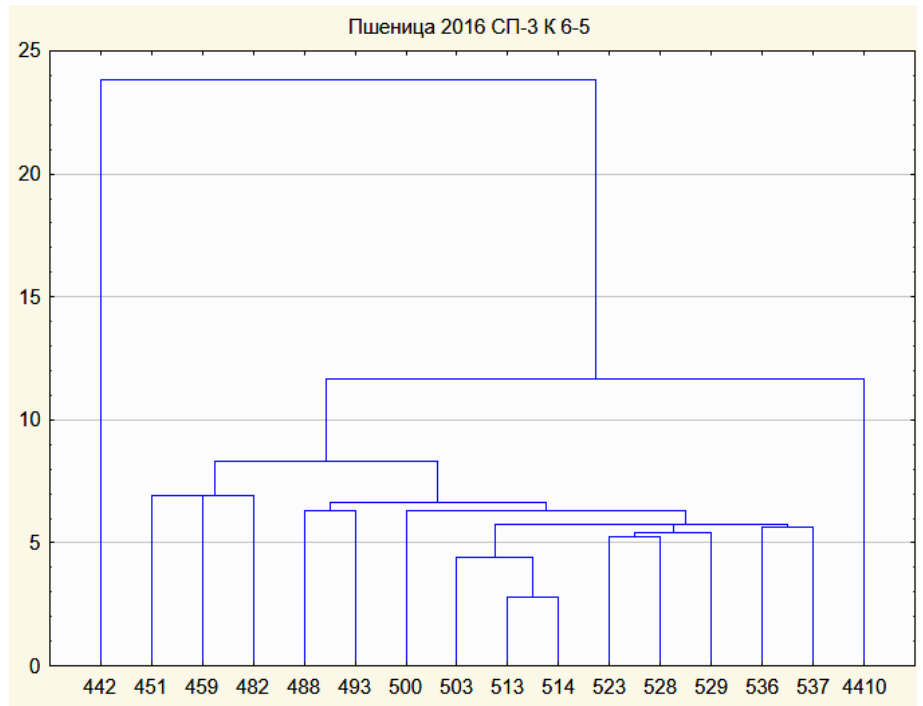

Рис. 8. Дендрограма розподілу сортів та селекційних ліній пиениці озимої в КГ 6-го кластеру, 2016 р., СП-3 


\section{СІЛЬСЬКЕ ГОСПОДАРСТВО. РОСЛИННИЦТВО}

За результатами кластерного аналізу встановлено, що в кращу групу кращого кластеру як по СП-1, так і по СП-3, ввійшли 11 сортів та селекційних ліній - №442(Одеська 267), №451 (Самара-2), №482 (Астра), №488 (Грація), №503 (Говтва); СЛ (№523, №529, №536, №537).

Концентрація одних і тих же сортів та СЛ за різними строками сівби в кращих групах кращих кластерів викликає велику зацікавленість в тому, що ці генотипи формують, як підтверджує статистичний аналіз $[1,2,9]$, високий рівень ознакскладових потенціалу врожайності. Причому строки сівби особливо не впливають на рівень їх формування.

За результатами досліджень 2016 року нами відмічена така особливість, що за наслідками кластерного аналізу 11 сортів та СЛ по двом строкам сівби були кращими за проявом кількісних ознак, але рівень сумарної відстані за Евклідовою метрикою був низький і не на всіх генотипах співпадав за величиною. Це стосується як сортів №442 (Одеська 267), №451 (Самара-2), №482 (Астра), №488 (Грація), №503 (Говтва), так і СЛ (№523, №529, №536, №537).

Таким чином, хоча одні і ті ж досліджувані сорти та СЛ пшениці озимої і попали в кращі

\section{БІБЛІОГРАФІЯ}

1. Гусенкова О. В., Тищенко В. М. Рівень формування і мінливість ознаки «маса зерна 3 колосу» сортів та селекційних ліній пшениці озимої в залежності від строків сівби : матеріали Міжнародної науково-практичної конференції, присвяченої 110-річчю від дня народження академікаселекціонера Василя Миколайовича Ремесла (с. Центральне, 20 жовтня 2017). - с. Центральне, 2017. - C. 27-28.

2. Гусенкова О. В., Тищенко В. М. Рівень формування кількості зерен з колосу пшениці озимої в залежності від строків сівби : матеріали Міжнародної науково-практичної конференції «Наукові засади підвищення ефективності сільськогосподарського виробництва», 23-24 жовтня 2017 р. - Харків : ХНАУ, 2017. - С. 127-129.

3. Касьяненко А. Н. использование многомерного статистического анализа в селекции растений // Тез. докл. Всесоюз. совещ. - Симферополь, Ялта. - 1989. - С. 38-39.

4. Ким Дж.-О., Мьюллер У., Клекка У. Р. и др. Факторный, дискриминантный и кластерный анализ. - М. : Финансы и статистика, 1989. $215 \mathrm{c}$.

5. Льссеко $A$. A. Сравнительная продуктивность сортов гороха различных морфотипов и создание на их основе нового селекционного ма- групи кращих кластерів і мають високий рівень збалансованості ознак потенціалу врожайності, але у них може проявлятись недостатня стабільність за строками сівби.

Ми вважаємо, і це доведено нашими попередніми дослідженнями $[8,10,11]$ : якщо величина рівень сумарної відстані у генотипів співпадають за строками сівби - вони збалансовані за господарськи корисними ознаками і проявляють високий рівень адаптивного потенціалу.

Висновок. На підставі проведених досліджень 3 використання кластерного аналізу в технології селекційного процесу протягом 2013-2016 років виділені сорти та константні селекційні лінії, збалансовані за господарськи корисними ознаками, які можуть бути використанні як перспективний селекційний матеріал $\mathrm{i}$ як батьківські компоненти при гібрідізації.

Перевага кластерного аналізу по відношенню до статистичного аналізу полягає в тому, що кластерний аналіз дає змогу ідентифікувати сорти і селекційні лінії за збалансованістю за господарськи корисними ознаками, а в статистичному аналізі ми можемо відібрати і виділити тільки окремі кількісні ознаки за їх рівнем формування і мінливості і за врожайністю.

териала : автореф. дис. ... к. с.-х. н. : 06.01.05. Зерноград, 2011. - 23 с.

6. Мартынов С. П. Кластерный анализ саратовских сортов яровой пшеницы по коэффициентам родства // Цитология и генетика. -23 , №4. - 1989. - С. 37-43.

7. Россеева Л. П., Белан И. А., Ложникова Л. Ф., Блохина Н. П., Валуева Л. Г. Повышение эффективности отбора по элементам продуктивности в гибридных популяциях с использованием кластерного анализа // Вестник Алтайского государственного аграрного университета. 2012. - №7 (93). - С. 5-8.

8. Тищенко B. М. Кластерний аналіз як метод індивідуального добору високопродуктивних рослин озимої пшениці в F2 // Селекція і насінництво. - Харків, 2005. - №89. - С. 125-137.

9. Тищенко В. М., Гусенкова О. В. Рівень формування і мінливість ознаки «кількість зерен колоса» у сортів та селекційних ліній пшениці озимої в залежності від строків сівби // Збірник наук. праць СГІ-НЦНС. - 2016. - Вип. 27(67). C. $183-188$.

10. Тищенко В. Н., Панченко П. М., Черньшева О. П. Идентификация сортов и селекционных линий пшеницы озимой по сбалансированности количественных признаков с использова- 
нием кластерного анализа // Вісник Полтавської державної аграрної академії, 2013. - №3 . - С. 28 35.

11. Тищенко В. Н., Чекалин Н. М., Зюков М. $E$. Использование кластерного анализа для идентификации и отбора высокопродуктивных генотипов озимой пшеницы на ранних этапах селекции // Зб. наук. праць Фактори експерименталь-

\section{ANNOTATION}

Tyshchenko V. M., Gusenkova O. V., Dubenets' M. V., Kolisnyk A. V. Systemization of sort and selection lines of wheat lines by numbership in conditions of controlled environment with using cluster analysis.

The article presents the results of four-year studies (2013-2016) on the determination of the balance of quantitative characteristics of varieties and selection lines of winter wheat by the use of cluster analysis. The experiment used 2 sowing lines: early (1 September, SP-1) and late (October 1, SP-3). The main goal, when analyzing the best groups and clusters, was the search for winter wheat varieties and breeding lines (SL), which in the statistical analysis had high indicators of two components of the harvest - the number of grains in the ear (KZ) and the mass of grain from the ear (M1). Also we investigate how in the best groups and on dendrograms varieties and genotypes were distinguished, which were better both in the first and in the third term sowing, not only in terms of the number of grains in the ear and the mass of grain from the ear, but also on other economic and valuable features and by yield.

It should be noted that the study of varieties, or SL by the terms of sowing, gives unique opportunities to evaluate the material under study in terms of the formation of quantitative ної еволюції організмів. - Т. 2. Аграрна наука, 2004. - C. 270-278.

12. Börner $A$. Preservation of plant genetic resources in the biotechnology era // Biotechnology $\mathrm{J}$. - 2006. - №1. - P. 1393-1404.

13. Kuruvadi S. Multivariate analysis of genetic divergence in wheat // Turrialba. 38, №4. - P. 267271 .

characteristics. We can form groups of varieties or SLs, where we will have information about the level of formation of signs at early, optimal, or late sowing. We can also distinguish genotypes as carriers of a high level of quantitative attributes, especially signs of yield potential in the early or late sowing, as the usual statistical analysis does not provide information on the balance of signs in one or another variety of winter wheat. We believe that cluster analysis makes it possible to identify varieties using the Euclidean metric in terms of the balance of quantitative attributes.

Based on the research carried out on the use of cluster analysis in the technology of breeding process for 2013-2016, selected varieties and constant selection lines are balanced by economically useful features that can be used as a promising breeding material and as parent components for hybridization.

The advantage of cluster analysis with respect to statistical analysis is that cluster analysis enables identification of varieties and breeding lines on a balance basis for economically useful features, and in the statistical analysis we can select and allocate only certain quantitative attributes according to their level of formation and variability and by yield.

Key words: winter wheat, signs, sowing dates, cluster analysis. 